\title{
PERANAN PSIKOLOGI PENDIDIKAN SEBAGAI KOMPETENSI DASAR PENDIDIK DAN TENAGA KEPENDIDIKAN
}

\section{Oleh}

\author{
PUTU SANJAYA
}

\begin{abstract}
Abstrak
Pendidikan adalah interaksi antara pendidik dengan peserta didik. Interaksi pendidikan selalu terkait dengan pengetahuan, pengembangan potensi, dan penanaman nilai-nilai, baik melalui proses pembelajaran, bimbingan ataupun latihan. Dalam interaksi ini individu berperilaku, dan perilaku menjadi bahan kajian psikologi pendidikan. Dengan demikian psikologi pendidikan adalah ilmu yang mengkaji tentang perilaku seseorang (khususnya peserta didik) dalam berinteraksi dengan lingkungan pendidikan. Seorang guru berkewajiban untuk memahami psikologi pendidikan, mengingat guru berinteraksi dengan siswa dan juga orang lain, yang lebih sering, dalam proses pendidikan.
\end{abstract}

\begin{abstract}
Education is the interaction between educators and learners. Educational interactions are always related to knowledge, potential development, and the cultivation of values, either through the process of learning, guidance or training. In this interaction individuals behave, and behaviors into study materials of educational psychology. Thus the psychology of education is the study of a person's behavior (especially learners) in interacting with the educational environment. A teacher is obliged to understand the psychology of education, considering that teachers interact with students and also others, more often, in the educational process.
\end{abstract}

\section{PENDAHULUAN}

Guru merupakan salah satu komponen penting dalam proses belajar mengajar. Seorang guru ikut berperan serta dalam usaha membentuk sumber daya manusia yang potensial di bidang pembangunan. Pengertian guru profesional menurut para ahli adalah semua orang yang mempunyai kewenangan serta bertanggung jawab tentang pendidikan anak didiknya, baik secara individual atau klasikal, di sekolah atau di luar sekolah. Guru adalah semua orang yang mempunyai wewenang serta mempunyai tanggung jawab untuk membimbing serta membina murid.
Keberhasilan pembelajaran kepada peserta didik sangat ditentukan oleh guru, sebab guru adalah pemimpin pembelajaran, fasilitator, dan sekaligus merupakan pusat inisiatif pembelajaran. Oleh karenanya, guru harus senantiasa mengembangkan kemampuan diri. Guru perlu memiliki standar profesi dengan menguasai materi serta strategi pembelajaran dan dapat mendorong siswanya untuk belajar bersungguhsungguh. Guru merupakan faktor yang sangat dominan dan penting dalam pendidikan formal pada umumnya karena bagi peserta didik, guru sering dijadikan tokoh teladan, bahkan menjadi tokoh 
identifikasi diri. Oleh karena itu, guru seharusnya memiliki perilaku kompetensi yang memadai untuk mengembangkan peserta didik secara utuh, sesuai tujuan pendidikan yaitu mengembangan potensi yang dimiliki peserta didik secara optimal.

Guru sebagai pendidik dalam UU RI No 20 Tahun 2003 tentang Sisdiknas dijelaskan sebagai tenaga professional yang bertugas merencanakan dan melaksanakan proses pembelajaran, menilai hasil pembelajaran, melakukan pembimbingan dan pelatihan, serta melakukan penelitian dan pengabdian kepada masyarakat, terutama bagi pendidik pada perguruan tinggi.

Terkait dengan profesinalisme, berdasarkan UU RI No.14 Tahun 2005 tentang Guru dan Dosen dinyatakan bahwa Guru adalah pendidik professional dengan tugas utama mendidik, mengajar, membimbing, mengarahkan, melatih, menilai, dan mengevaluasi peserta didik pada pendidikan anak usia dini jalur pendidikan formal, pendidikan dasar, dan pendidikan menengah. Sebagai pendidik professional, sesuai dengan Undangundang Nomor 14 Tahun 2005 tentang Guru dan Dosen pada Bab IV Pasal 10 guru harus memiliki empat kompetensi guru, yakni Kompetensi Pedagogik, Kompetensi Kepribadian, Kompetensi Profesional, dan Kompetensi Sosial. Keempat kompetensi tersebut harus dimiliki guru, diminta ataupun tidak, mereka harus melakukannya secara tulus. Keempat kompetensi tersebut tidak berdiri sendiri, melainkan saling berhubungan dan saling memengaruhi, serta saling mendasari satu sama lain.

Dalam melaksanakan proses pendidikan, guru sebagai pendidik bekerjasama dengan tenaga kependidikan. Pengertian tenaga kependidikan dalam UU RI No 20 Tahun 2003 mengenai
Sisdiknas adalah anggota masyarakat yang mengabdikan diri dan diangkat untuk menunjang penyelenggaraan pendidikan. Tenaga kependidikan bertugas melaksanakan administrasi, pengelolaan, pengembangan, pengawasan, dan pelayanan teknis untuk menunjang proses pendidikan pada satuan pendidikan. Di sekolah, baik siswa, guru, dan tenaga kependidikan lainnya melakukan interaksi pendidikan sebagai bagian dari proses pendidikan itu sendiri. Interaksi sebagi aktualisasi dari perilaku harus dapat dipahami dan dkelola dengan baik oleh guru dan juga tenaga kependidikan yang lainnya, sehingga menjadi sebuah keharusan bagi guru dan tenaga kependidikan lainnya untuk tahu dan memahami tentang psikologi pendidikan.

\section{PEMBAHASAN}

\subsection{Standar Pendidik dan Tenaga Kependidikan dalam PP No 19 Tahun 2005 tentang Standar Nasional Pendidikan}

Standar Nasional Pendidikan dalam PP No.19/2005 adalah kriteria minimal tentang sistem pendidikan diseluruh wilayah hukum NKRI yang mencakup 8 (delapan) standar yakni standar kompetensi lulusan, standar isi, standar proses, standar pendidik dan tenaga kependidikan, standar sarana dan prasarana, standar pengelolaan, standar pembiayaan, serta standar penilaian. Adapaun dalam makalah ini hanya khusus membahas tentang standar pendidik dan tenaga kependidikan.

Berdasarkan PP No19/2005 definisi dari standar pendidik dan tenaga kependidikan adalah kriteria pendidikan jabatan dan kriteria pendidikan prajabatan dan kelayakan fisik maupun mental, serta pendidikan dalam jabatan. Pada Bab IV 
bagian Kesatu mengenai pendidik dijelaskan bahwa pendidik harus memiliki kualifikasi akademik dan kompetensi sebagai agen pembelajaran, sehat jasmani dan rohani, serta memiliki kemampuan untuk mewujudkan tujuan pendidikan nasional, dengan mengindahkan peraturan mengenai tingkat pendidikan minimal yang dibuktikan dengan ijazah, serta memiliki memenuhi 4 (empat) kompetensi yang terdiri dari kompetensi pedagogik, kompetensi kepribadian, kompetensi profesional, dan kompetensi sosial. Janawi (2012:47) menjelaskan sebagai berikut:

\section{A. Kompetensi Pedagogik}

Kompetensi pedagogik
berkaitan langsung dengan penguasaan disiplin ilmu pendidikan dan ilmu lain yang berkaitan dengan tugasnya sebagai guru. Oleh karena itu guru (pendidik) harus memiliki latar belakang pendidikan keguruan yang relevan dengan bidang keilmuannya. Secara teknis kompetensi pedagogik ini meliputi:

a. Menguasai karakter peserta didik

b. Menguasai teori dan prinsipprinsip pembelajaran

c. Mengembangkan kurikulum dan prinsip-prinsip pembelajaran

d. Menyelenggarakan pembelajaran yang mendidik

e. Memanfaatkan TIK untuk kepentingan pembelajaran

f. Memfasilitasi pengembangan potensi peserta didik

g. Berkomunikasi secara efektif, empatik, dan santun dengan peserta didik

h. Menyelenggarakan evaluasi dan penilaian proses dan hasil belajar i. Memanfaatkan hasil evaluasi dan penilaian untuk kepentingan pembelajaran

j. Melakukan tindakan refleksi untuk peningkatan kualitas pembelajaran

B. Kompetensi Profesional

Kompetensi profesional merupakan kemampuan dasar tenaga pendidik. Ia akan disebut profesional jika mampu menguasai keahlian dan keterampilan teoritik dan praktik dalam proses pembelajaran. Kompetensi ini cenderung mengacu kepada kemampuan teoritik dan praktik lapangan. Secara rinci kemampuan professional dapat dijabarkan sebagai berikut:

a. Menguasai materi, struktur, konsep dan pola pikir keilmuan yang sesuai dan mendukung bidang keahlian/bidang studi yang diampu

b. Memanfaatkan TIK untuk meningkatkan kualitas pembelajaran sesuai bidang studi yang diampu

c. Menguasai filosofi, metodologi, teknis, dan fraksis penelitian dan pengembangan ilmu yang sesuai dan mendukung bidang keahliannya

d. Mengembangkan diri dan kinerja profesionalitasnya dengan melakukan tindakan reflektif dan penggunaan TIK

e. Meningkatkan kinerja dan komitmen dalam pelaksanaan pengabdian masyarakat

C. Kompetensi Kepribadian

Kompetensi kepribadian meliputi kemampuan personalitas, 
jati diri sebagai seorang tenaga pendidik yang menjadi panutan bagi peserta didik. Kompetensi inilah yang selalu menggambarkan prinsip bahwasanya guru adalah sosok yang patut digugu dan ditiru. Dengan kata lain guru menjadi suri tauladan bagi peserta didik atau guru menjadi sumber dasar bagi peserta didik dalam berperilaku. Secara khusus kompetensi kepribadian dapat dijabarkan sebagai berikut:

a. Berjiwa pendidik dan bertindak sesuai dengan norma agama, hukum, sosial, dan kebudayaan nasional Indonesia

b. Tampil sebagai pribadi yang jujur, berahlak mulia dan menjadi teladan bagi peserta didik dan masyarakat

c. Tampil sebagai pribadi yang mantap, dewasa, stabil dan berwibawa

d. Menunjukkan etos kerja, tanggung jawab, rasa bangga sebagai tenaga pendidik dan rasa percaya diri.

D. Kompetensi Sosial

Kompetensi

sosial

berkaitan dengan kemampuan guru berinteraksi dengan peserta didik dan orang yang ada di sekitar dirinya. Modal interaksi berupa komunikasi personal yang dapat diterima oleh peserta didik dan masyarakat. Dalam konteks ini hendaknya guru memiliki strategi dan pendekatan dalam melakukan komunikasi yang mengarah pada proses pembentukan masyarakat belajar (learning community). Kompetensi sosial dapat diuraikan sebagai berikut:

a. Bersifat inklusif dan bertindak obyektif b. Beradaptasi dengan lingkungan tempat bertugas dan dengan lingkungan masyarakat

c. Berkomunikasi secara efektif, empatik, dan santun dengan komunitas profesi sendiri maupun profesi lain, secara lisan dan tulisan atau bentuk lain

d. Berkomunikasi secara empatik dan santun dengan masyarakat luas

Keempat kompetensi tersebut diatas sewajibnya dimiliki dan dilaksanakan oleh guru sebagai bentuk profesionalitasnya. Ada tiga hal utama yang dijadikan sebagai ukuran profesionalitas seorang guru yaitu: Pertama, tingkat pendidikan minimal. Hal ini dapat dilihat dari latar belakang pendidikan untuk jenjang sekolah dimana dia menjadi guru; Kedua, penguasaan guru terhadap materi atau bahan ajar, mengelola proses pembelajaran, mengelola siswa, dan melakukan tugastugas bimbingan; Ketiga, memiliki sertifikat pendidik. Dengan memiliki dan menguasai tiga hal tersebut, maka seorang guru dapat diukur keprofesionalannya.

\subsection{Peranan Psikologi Pendidikan dalam Standar Pendidik dan Tenaga Kependidikan}

Salah satu pendukung profesionalitas guru, adalah pemahaman terhadap materi Psikologi Pendidikan.Psikologi pendidikan adalah ilmu yang mengkaji tentang perilaku seseorang (khususnya peserta didik) dalam berinteraksi dengan lingkungan pendidikan. Sukmadinata (2011:5) menjelaskan bahwa lingkungan pendidikan adalah lingkungan terjadinya proses pendidikan. Lingkungan pendidikan terdiri dari lingkungan fisik, 
sosial, intelektual, dan nilai-nilai. Lingkungan fisik adalah fasilitas atau sarana dan prasana yang mendukung proses pendidikan. Lingkungan sosial adalah lingkungan pergaulan antar manusia dalam interaksi pendidikan. Lingkungan intelektual adalah kondisi dan iklim sekitar yang mendorong dan menunjang pengembangan intelektual, baik berupa program-program kegiatan pembelajaran, ataupun aktivitas-aktivitas yang dirancang untuk menumbuhkembangkan kemampuan berpikir. Lingkungan lainnya adalah lingkungan nilai yang berupa tatanan kehidupan yang sifatnya normatif seperti etika, adat, agama, ataupun nilai yang berlaku dalam kehidupan bermasyarakat.

Pendidikan pada dasarnya adalah interaksi antar individu dalam lingkungan pendidikan. Atau dapat pula dikatakan individu melakukan interaksi dengan lingkungan pendidikan. Pendidikan adalah interaksi antara pendidik dengan peserta didik. Interaksi pendidikan selalu terkait dengan pengetahuan, pengembangan potensi, dan penanaman nilai-nilai, baik melalui proses pembelajaran, bimbingan ataupun latihan. Dalam interaksi inilah individu berperilaku dan menjadi bahan kajian psikologi pendidikan

Pendidikan di Indonesia saat ini bisa dikatakan tengah mengalami masalah besar. Hal itu bisa dilihat dari pelaksanaan Kurikulum 2013 yang belum merata, ketidakmeratanya kesempatan memperoleh pendidikan, kasus pelecehan dan kekerasan seksual di sekolah, oknum pendidik yang terjerat masalah hukum dan tindak pidana, tawuran antar siswa, mahasiswa yang terlibat masalah narkoba, dsb. yang mengindikasikan bahwa semakin rendahnya perilaku masyarakat yang notabene adalah insan-insan pendidikan. Hal ini tentunya membutuhkan antisipasi yang cepat dan tepat agar tidak menjalar mempengaruhi stabilitas kehidupan dengan berbagai macam aspeknya.

Jabatan guru atau pendidik merupakan suatu jabatan yang amat strategis dalam menunjang proses dan hasil kinerja pendidikan secara keseluruhan. Oleh karena itu dapat dikatakan bahwa guru sebagai pendidik merupakan gerbang awal sekaligus sebagai representasi kondisi dan kinerja pendidikan. Hal ini mengandung makna bahwa kinerja seorang guru akan banyak memberikan pengaruh yang cukup bermakna bagi perwujudan kinerja pendidikan secara efektif. Dalam hubungan ini penampilan seorang pendidik harus terwujud sedemikian rupa secara efektif sehingga dapat menunjang dinamika dan keefektifan pendidikan. Kinerja penampilan pendidik didukung sejumlah kompetensi tertentu yang berlandaskan kepribadian. Agar hal itu dapat terwujud maka seorang pendidik harus memahami hal-hal yang berkaitan dengan penampilan kepribadian serta menguasai sejumlah kompetensi yang melandasinya. Selanjutnya berbagai unsur yang menunjang kualitas keefektifan kepribadian harus dapat diwujudkan secara nyata. Kesuksesan kinerja pendidik juga didukung oleh unsur kewibawaan yang ada dalam pribadinya (Surya, 2013:249)

Lantas apa kegunaan Psikologi Pendidikan dalam konteks ini? Dalam kehidupan nyata seseorang selalu ingin bisa dipahami dan diharapkan bisa memahami dalam sebuah interaksi. Seseorang selalu pernah mengalami atau menemukan masalah dan dituntut untuk bisa memahami dan menyelesaikan masalah. Kemampuan dalam menentukan sikap sesungguhnya menjadi bisa menjadi ukuran kedewasaan seseorang ketika ia berada dalam situasi tersebut. Pengetahuan akan psikologi sungguh 
sangat membantu dalam bersikap. Surya (2013:22) menjelaskan bahwa sekurangkurangnya ada tiga sasaran psikologi ilmiah yaitu: Pertama, memperoleh pemahaman mengenai individu manusia dengan segala keunikan latar belakangnya, mekanismenya, dan dinamikanya; Kedua, memberikan deskripsi, prediksi, dan pengendalian terhadap perilaku individu manusia; dan Ketiga, memberikan peluang bagi seseorang untuk lebih memahami diri sendiri dan orang lain. Berdasarkan hal tersebut, sesungguhnya semua orang perlu mengetahui tentang psikologi. Hal itu akan membantu dalam kepekaan pada situasi dan kondisi yang diikuti kesadaran untuk bersikap.

Dalam lingkungan pendidikan, guru sebagai figur utama dalam lingkungan pendidikan formal wajib hukumnya memiliki pengetahuan psikologi guna memperoleh pemahaman yang tepat mengenai perilaku anak didiknya. Keteledoran seorang guru yang tak memahami psikologi adalah kekeliruan pengambilan keputusan terhadap sebuah permasalahan yang dialami oleh anak didiknya terlebih lagi sampai ada intervensi kepentingan pribadi. Hal itu sungguh fatal. Oleh karena itu psikologi pendidikan merupakan ilmu pengetahuan yang harus dimiliki oleh setiap pendidik. Pendidik yang memahami perilaku anak didik dengan baik akan membantu mewujudkan interaksi pendidikan yang harmonis dan bermanfaat dalam membantu pengembangan potensi dalam diri anak didik.

\subsection{Peranan Psikologi Pendidikan bagi Pendidik (Guru dan Dosen)}

Iskandar (2009: 6-8) menjelaskan bahwa seorang pendidik dalam menjalankan perannya sebagai pengajar, pembimbing, pendidik, dan pelatih bagi para murid, siswa dan mahasiswa (peserta didiknya) tentunya dituntut untuk memahami dan menguasai tentang berbagai aspek perilaku dirinya maupun perilaku orang-orang yang terkait dengan tugasnya, sehingga dapat menjalankan tugas dan perannya secara efektif dan efesien, yang pada gilirannya dapat memberikan kontribusi nyata bagi pencapaian tujuan pendidikan. Disinilah letak arti pentingnya psikologi pendidikan bagi pendidik. Penguasaan pendidik tentang psikologi pendidikan merupakan salah satu kompetensi yang harus dikuasai guna menciptakan suasana hubungan yang harmonis sehingga tujuan pendidikan dapat tercapai.

Pemahaman terhadap psikologi pendidikan oleh seorang pendidik dengan melalui pertimbangan-pertimbangan psikologis maka pendidik diharapkan dapat:

1. Merumuskan tujuan pembelajaran secara tepat. Dengan memahami psikologi pendidikan yang memadai diharapkan pendidik akan dapat menentukan bentuk perubahan perilaku yang dikehendaki sebagai tujuan pembelajaran dengan lebih tepat.

2. Memilih strategi atau metode pembelajaran yang sesuai. Dengan memahami psikologi pendidikan yang memadai diharapkan guru dapat menentukan strategi atau metode pembelajaran yang tepat dan sesuai, dan mampu mengaitkannya dengan karakteristik dan keunikan individu, jenis belajar, gaya belajar dan tingkat perkembangan siswa.

3. Memberikan bimbingan atau konseling. Selain melaksanakan pembelajaran, tugas dan peranan guru juga membimbing siswanya. Dengan memahami psikologi pendidikan diharapkan pendidik dapat memberikan bantuan 
psikologis secara tepat dan benar dengan melalui proses hubungan interpersonal yang penuh keakraban dan kehangatan.

4. Memfasilitasi dan memotivasi belajar peserta didik. Memfasilitasi artinya berusaha untuk mengembangkan segenap potensi yang dimiliki siswa, seperti bakat, minat, dan kecerdasan. Sedangkan memotivasi dapat diartikan berupaya memberikan dorongan kepada siswa untuk melakukan perbuatan tertentu, khususnya perbuatan belajar. Tanpa pemahaman psikologi pendidikan yang memadai, pendidik akan mengalami kesulitan untuk mewujudkan dirinya sebagai fasilitator maupun motivator belajar siswanya.

5. Menciptakan iklim belajar yang kondusif. Efektifitas pembelajaran membutuhkan adanya iklim belajar yang kondusif. Pendidik dengan pemahaman psikologi pendidikan yang memadai memungkinkan untuk dapat menciptakan iklim sosio emosional yang kondusif di dalam kelas sehingga siswa dapat belajar dengan nyaman dan menyenangkan.

6. Berinteraksi secara tepat dengan siswa. Pemahaman pendidik tentang psikologi pendidikan memungkinkan untuk terwujudnya interaksi dengan siswa secara lebih bijak, penuh empati dan menjadi sosok yang lebih menyenangkan dihadapan siswanya.

7. Menilai atau mengevaluasi hasil pembelajaran yang adil. Pemahaman pendidik tentang psikologi pendidikan dapat membantu pendidik dalam mengembangkan penialaian pembelajaran siswa yang lebih adil, baik dalam teknis penilaian atau pemenuhan prinsip-prisnsip penilaian, maupun menentukan hasil-hasil penilaian.

\subsection{Peranan Psikologi Pendidikan bagi Tenaga Kependidikan}

Menurut Wikipedia (diakses 3 Maret 2015) dijelaskan bahwa Tenaga Kependidikan adalah anggota masyarakat yang mengabdikan diri dan diangkat untuk menunjang penyelenggaraan pendidikan. Adapun yang termasuk kedalam tenaga kependidikan adalah:

\section{Kepala Satuan Pendidikan}

Kepala Satuan Pendidikan yaitu orang yang diberi wewenang dan tanggung jawab untuk memimpin satuan pendidikan tersebut. Kepala Satuan Pendidikan harus mampu melaksanakan peran dan tugasnya sebagai edukator, manajer, administrator, supervisor, leader, inovator, motivator, figur dan mediator (Emaslim-FM) Istilah lain untuk Kepala Satuan Pendidikan adalah: Kepala Sekolah, Rektor, Direktur, serta istilah lainnya.

\section{Tenaga Kependidikan lainnya}

Tenaga Kependidikan lain yang dimaksud disini adalah orang yang berpartisipasi dalam penyelenggaraan pendidikan di satuan pendidikan, walaupun secara tidak langsung terlibat dalam proses pendidikan, diantaranya: a) Wakil-wakil/Kepala urusan umumnya pendidik yang mempunyai tugas tambahan dalam bidang yang khusus, untuk membantu Kepala Satuan Pendidikan dalam penyelenggaraan pendidikan pada institusi tersebut. Contoh: Kepala Urusan Kurikulum; b) 
Tata usaha, adalah Tenaga Kependidikan yang bertugas dalam bidang administrasi instansi tersebut. Bidang administrasi yang dikelola diantaranya administrasi surat menyurat dan pengarsipan, administrasi Kepegawaian, administrasi peserta didik, administrasi Keuangan, administrasi inventaris dan lain-lain; c) Laboran, adalah petugas khusus yang bertanggung jawab terhadap alat dan bahan di laboratorium; d) Pustakawan; e) Pelatih ekstrakurikuler; f) Petugas keamanan (penjaga sekolah), Petugas kebersihan, dan lainnya.

$$
\text { Sementara itu dalam }
$$

faperta.unand.ac.id (diakses 3 Maret 2015) dijelaskan bahwa tugas dan tanggung jawab tenaga kependidikan adalah:

1. Tenaga kependidikan dalam kapasitasnya adalah fasilitator administrasi untuk mendukung semua kegiatan di fakultas.

2. Setiap tenaga kependidikan berkewajiban mendukung pekerjaan administratif pada setiap lini gugus tugas, mulai dari tingkat fakultas, jurusan, dan program studi.

3. Segenap tenaga kependidikan berkewajiban untuk menjalankan kelancaran dan menertibkan administrasi akademik, laboratorium, pustaka, kemahasiswaan, maupun unit-unit lainnya.

4. Setiap penyimpangan dan pelanggaran dalam menjalankan kegiatan akademik, dikenakan sanksi sesuai dengan ketentuan dan perundang-undangan yang berlaku.

5. Seorang tenaga kependidikan dilarang: a) Memalsukan nilai, surat-surat, dan/atau dokumen persyaratan akademik; b)
Membocorkan soal-soal ujian dan/atau memberikan kesempatan untuk itu; c) Menerima pemberian dalam bentuk apa pun dari pihak manapun yang terkait dengan nilai atau kewajiban administrasi lainnya.

6. Memperlakukan siswa/mahasiswa diluar kepatutan, seperti mempersulit dalam kegiatan administrasi akademik, memperlakukan mahasiswa tidak adil, dan hal-hal yang kurang pantas.

Lebih lanjut bahwa peranan tenaga kependidikan adalah sebagai administrator. Jika tenaga kependidikan tersebut memiliki staf, maka peranannya bertambah satu yaitu sebagai pengelola (manager). Manajer ialah seorang yang mampu melihat semua urusan dalam keseluruhannya, melimpahkan pekerjaannya, membangkitkan gairah kerja, memberikan insipasi, membimbing stafnya, bekerja sama, dan menerapkan teknik-teknik administrasi perkantoran. Sebagai seorang administrator, ia harus memahami dan mampu mengkoordinasikan penyelenggaraan administrasi lembaga pendidikan sesuai pedoman pengelolaan administrasi lembaga pendidikan. Jadi, seorang administrator harus mampu sebagai koordinator. Di samping itu, ia juga harus mampu menciptakan pelayanan administrasi yang lancar dan tepat waktu. Peranan kepala tenaga kependidikan sebagai manajer lainnya lagi adalah sebagai planner karena ia harus membuat rencana dan program kerja ketatausahaan. Serta sebagai organisator karena ia juga harus mengorganisasikan stafnya.

Menyimak uraian diatas maka dapat sekiranya dijabarkan bahwasanya peranan psikologi pendidikan bagi tenaga kependidikan adalah sebagai berikut: 
1. Merancang dan menyusun atau mengembangkan program pendidikan berdasarkan kebutuhan peserta didik. Pengetahuan dan pemahaman akan psikologi pendidikan dan peserta didik bagi tenaga kependidikan akan memudahkan penyusunan, perancangan, dan pengembangan program-program pendidikan yang bermanfaat bagi peserta didik dan lembaga pendidikan secara efektif dan efesien.

2. Mewujudkan kerjasama antar persona tenaga kependidikan dan suasana kerja yang dinamis, kompetitif, sehat dan hangat. Adanya pemahaman pada karakteristik dan kepribadian masing-masing rekan kerja, yang bisa diperoleh dari pengetahuan psikologi pendidikan, akan memudahkan kerjasama dalam bekerja baik dalam komunikasi, koordinasi, maupun menjaga integritas dan kesatuan tenaga kependidikan.

3. Memberikan pelayanan kepada kostumer pendidikan (siswa, orang tua siswa, komite, stakeholder, masyarakat) dengan lebih antusias, empati, dan prima. Kinerja dan produktivitas tenaga kependidikan akan dapat lebih ditingkatkan bila memiliki pengetahuan dan pemahaman psikologi pendidikan sehingga dalam memberikan pelayanan kepada pihak yang memerlukan akan dapat berjalan dengan prima.

4. Mewujudkan peningkatan integritas personal yang berdampak pada kualitas dan popularitas positif lembaga pendidikan di mata masyarakat. Psikologi pendidikan dapat membantu mewujudkan nilai diri setiap personal tenaga kependidikan dikarenakan menjalankan tugas sesuai dengan struktur dan fungsi sehingga terbentuk integritas yang bermuara kepada meningkatnya kualitas lembaga pendidikan yang diakui oleh masyarakat.

\section{Penutup}

Pemaparan diatas telah menjelaskan bahwa secara umum baik guru maupun tenaga kependidikan lainnya adalah orang yang memiliki kedewasaan yang telah mempersiapkan dirinya untuk menjalankan tugas sebagai pendidik, pembimbing, pengajar, pelatih, serta fasilitator bagi peserta didik dalam menyukseskan tujuan pendidikan itu sendiri. Psikologi pendidikan pada dasarnya memiliki tujuan utama yakni agar para guru atau para pendidik memiliki pemahaman yang lebih baik tentang situasi pendidikan. Disamping itu pula para pendidik juga mampu merancang, merencanakan, menyiapkan, melaksanakan, serta mengevaluasi proses pendidikan dengan lebih baik.

Berdasarkan uraian diatas, dapatlah diambil sebuah kesimpulan bahwa untuk bisa melaksanakan proses pendidikan dan pembelajaran yang baik dan sukses, pengetahuan dan pemahaman akan Psikologi Pendidikan bagi pendidik dan tenaga kependidikan sungguh mutlak untuk dikuasai. Hal itu dimaksudkan agar terciptanya interaksi yang baik dan kondusif, normatif dan penuh nilai-nilai luhur demi terwujudnya tujuan pendidikan yang dicita-citakan.

\section{Pustaka yang Diacu:}

Aqib, Zainal. 2013. Pengembangan Keprofesian Berkelanjutan Bagi Guru. Bandung Yrama Widya 
Danim, Sudarwan. 2011. Pengembangan Profesi Guru. Jakarta: Kencana Prenada Media Group

Janawi. 2012. Kompetensi Guru Citra Guru Profesional. Bandung: Alfabeta

Kunandar. 2008. Guru Profesional. Jakarta: RajaGrafindo Persada

Kurinasih, Imas \& Sani, Berlin. 2014. Sukses Mengimplementasikan Kurikulum 2013. Katapena.penerbit@gmail.com

Peraturan Pemerintah RI No.19 Tahun 2005 tentang Standar Nasional Pendidikan

Sagala, Syaiful. 2009. Kemampuan Profesional Guru dan Tenaga Kependidikan. Bandung: Alfabeta
Sukmadinata, Nana Syaodih. 2011. Landasan Psikologi Proses Pendidikan. Bandung: Remaja Rosdakarya

Surya, Mohamad. 2013. Psikologi Guru Konsep dan Aplikasi. Bandung: Alfabeta

Suyanto \& Djihad, Asep. 2012. Bagaimana Menjadi Calon Guru dan Guru Profesional. Yogyakarta: Multi Pressindo

Undang-undang Guru dan Dosen UU RI No.14 Tahun 2005

Undang-undang Sistem Pendidikan Nasional UU RI No.20 Tahun 2003 